Multiplatform news consumption and its connections to civic engagement

\section{Logan Molyneux}

Temple University, USA
2019, Vol. 20(6) 788-806

(C) The Author(s) 2017

Article reuse guidelines: sagepub.com/journals-permissions DOI: I0.II77/|4648849|77302। 6 journals.sagepub.com/home/jou

\begin{abstract}
Studies of informational media use have focused on individual platforms or pitted platforms against each other when investigating their connections to civic engagement. This study offers evidence, collected in a 2016 survey of US adults, of how civically engaged individuals consume various types of news content across multiple platforms. Results suggest that the best condition is the most varied one, wherein consumers get news on all six platforms studied. A breakdown of content categories finds that television viewers and those who pay attention to breaking news and crime are less civically engaged.
\end{abstract}

\title{
Keywords
}

Civic engagement, media platforms, multimedia, news, news content

A number of factors are known to affect one's propensity toward civic engagement, including age, socioeconomic status, education, civic training, sense of community, and so on. But none of these elements have changed the way the information environment has changed in the 21 st century. As Patterson (2013) puts it, we live in an informationpoor environment, and changes in communication are largely to blame. While there are certainly other institutions responsible for encouraging democratic public deliberation schools and families, for instance - Patterson argues that journalists are

\section{Corresponding author:}

Logan Molyneux, Klein College of Media and Communication, Temple University, 2020 N. I3th Street,

Philadelphia, PA 19122, USA.

Email: logan@temple.edu 
the 'chief sense-makers' in Western democracies, and it is 'nearly impossible to have sensible public deliberation when large numbers of people are out of touch with reality' (p. 5). The information supply from news media is crucial to civic engagement (Neuman et al., 2011; Zukin et al., 2006).

At one time, it was common to study platform and content in binary terms. Scholars analyzed types of information supplied by the two most widely used news platforms: print and broadcast (Verba et al., 1995), and these were perceived to have different strengths. When these news media began infusing their offerings with entertainment in an effort to hang on to audiences dispersed by cable and the Internet, studies began looking at how this new 'soft news' compared to 'hard news' (Neuman et al., 1992; Prior, 2003; Reinemann et al., 2011). The consensus was that not all forms of content were equally productive. But in today's fractured media landscape, 'news media' describes a multitude of outlets, large and small, professional and run by citizens, producing a wide array of content distributed on a range of physical and digital platforms that, like the legacy platforms, are also infused with entertainment and other forms of media and communication. Now that news is decoupled from its delivery format (e.g. the 'newspaper' also publishes on computers, smartphones, watches, and so on), does the platform through which one receives information matter as it once did in contributing to civic engagement? Are there meaningful distinctions in news content beyond hard and soft, and how might kinds of content contribute to civic engagement?

This study takes up these intertwined questions of content and platform with a survey of US adults, asking them about their news consumption habits on various platforms and of a range of news subjects. The goal is to move beyond dichotomized distinctions in platform (new media vs traditional, textual vs visual) and content (hard vs soft) to inform an understanding of the role multimedia, multiplatform news consumption plays in democratic society.

\section{News and civic engagement}

Civic engagement is perhaps the broadest possible term for the set of activities that are 'designed to identify and address issues of public concern' (Delli Carpini Michael, n.d.). This includes all forms of participation (which can now be separated into civic and political segments), as well as more basic activities like information gathering and even some attitudes or states of mind (one may be considered engaged if one simply cares about public affairs). However, it is common practice for these elements of engagement to be placed in sequence relative to each other, with some occurring as antecedents of others. At the end of this sequence is generally forms of civic and political participation, and that is where this study focuses. Thus, the term 'civic engagement' is used herein to refer to civic and political participation collectively, treating media use as a separate concept and an antecedent of civic engagement.

Informational media use has long been associated with civic engagement (Lane, 1959; Verba et al., 1995; Verba and Nie, 1972) on the assumption that information is a resource on which people draw when participating in civic affairs. The more of this resource a person has, the more likely they see themselves as a capable participant and the more prepared they are to act. Researchers have often studied the relationship 
between news consumption on a particular platform and civic engagement. This started with measurements of how often people read newspapers (Lane, 1959). Television, in particular, has been singled out as an enemy of civic engagement. It has been blamed for causing declines in American social life because of the way it privatizes leisure time (Putnam, 2000) and offers so many choices (many focused solely on entertainment) that people can ignore or avoid civic information (Prior, 2003, 2005). The wide range of channels available leads people to switch among them, minimizing the chances of consuming informational content even accidentally (Hardy and Jamieson, 2011; Morris and Forgette, 2007). Subsequent research has suggested that people are not always so selective in their media choices, and that media effects depend on the type of media consumed (Norris, 1996; Shah, 1998). Indeed, a person's attitudes (and not the television itself) may be responsible for declines in civic engagement (Uslaner, 1998).

Overall, studies comparing platforms for news have found that newspapers are better than television and Internet at conveying information and salience, largely because of the depth and detail inherent in their textual presentations (Althaus and Tewksbury, 2002; Eveland and Dunwoody, 2002; McCombs, 2004; Neuman et al., 1992; Santana et al., 2013; Tewksbury and Althaus, 2000; Tien-Tsung et al., 2008; Yang and Grabe, 2011). This transfer of information and salience equips a person to participate in civic life. Positive connections between digital media use and civic engagement have been found by numerous studies (Beaudoin, 2009; Fleming and Thorson, 2008; Gil de Zúñiga et al., 2012; Gil de Zúñiga et al., 2014; Price et al., 2006; Sayre et al., 2010; Scheufele and Shah, 2000). After reviewing the literature, Neuman, Bimber, and Hindman conclude that, overall, there is a 'modest association' between use of the Internet and civic engagement (Neuman et al., 2011). Studies of mobile phone use have suggested a similar connection (Campbell and Kwak, 2010, 2011; Kwak et al., 2011).

Usually implicit in these studies of platforms are variations in the content of news messages themselves. Public affairs news consistently outperforms other forms of information in encouraging participation in public life. Studies have suggested that consumption of other forms of media content may also make positive contributions to civic life (Tewksbury et al., 2001; Entman, 2005; Gil de Zúñiga et al., 2014; Prior, 2003), usually on the basis that some information about one's community is better than none. But overall, research in this vein has focused largely on broad content distinctions (hard vs soft news), or the effects of a single platform on civic engagement (as in the cases of computers and mobile devices) or in comparing platforms (newspaper vs television) or categories of platforms (digital media vs traditional media). Rather than categorizing media in this fashion, it may be more helpful to identify some dimensions along which these platforms differ in systematic ways.

\section{Platforms for news}

The term 'platform' in this study refers to the physical technology used to convey media messages: paper, television, computer, smartphone, and tablet. Some media services or infrastructures also have been called platforms, including cable, the Internet, and some individual social media (e.g. Twitter as a microblogging platform). In some cases, these are restricted to a single physical technology (cable to the television) but not in others 
(internet and social media are present on multiple devices). In order to talk about platforms in a way that is mutually exclusive, 'platform' is interpreted to mean the physical technology. 'Content' refers to the messages relayed via the platform.

Different platforms enable different patterns of news presentation and consumption because of the affordances of the platform, that 'mix of attributes' (Eveland, 2003) that defines what media are capable of and describes what they most often do. Building on the work of Eveland and others, below are the attributes of media platforms that seem most likely to distinguish their contributions to civic engagement. These attributes are not measured in this study, but are presented to help conceptually distinguish the relative strengths and weaknesses of media platforms and content in presenting the information vital to civic engagement. Thus, if one platform makes greater contributions to civic engagement, we may deduce that this is because of how it differs from other platforms in terms of information density, immediacy, normalization, and interactivity.

\section{Information density}

If information is the resource needed to participate in public life, it makes sense that platforms that present more of it, or present it more efficiently, should make a greater contribution. This is evident in studies finding textual media, with their ability to convey relatively complicated information, to be better at promoting civic engagement. It may be more useful to think of the relative density of information on a platform, which considers both the amount available and the space (either temporal or physical) it is presented in (see Eveland's (2003) conception of 'organization'). How much information is available through a single hub or portal (e.g. a home page or an app)? How much time is necessary to view all available content (i.e. a 30-minute evening newscast vs 30 -minute reading news online)? Are news stories generally longer or shorter? Do the stories provide more or less depth? Newspapers and news websites might be considered more information dense than television news and mobile news.

\section{Immediacy}

This dimension considers consumers' ability to access news in real time, potentially giving them an informational advantage. This is a combination of the speed with which information is conveyed and the degree of separation between occurrence and consumption. Television news often goes 'live', but this experience is more orchestrated than the livestreams now available through Facebook Live and Periscope on mobile phones. A mobile news app is more immediate than a computer-based website (once considered the pinnacle of up-to-the-minute news coverage), given that it can be always with you (Dholakia et al., 2014; Dimmick et al., 2010; Ruston, 2012). Newspapers, obviously, would have the lowest immediacy and highest degree of editorial filtration.

\section{Normalization}

Calling a platform 'traditional' often refers to the degree of journalistic normalization on that platform. That is, to what extent have journalists adapted to a platform, building up 
systems and routines around it, such that it may be considered a 'normal' part of journalism and no longer subject to experimentation (Singer, 2005). Journalists working in more normalized spaces may expend less effort on adaptation and more on the coverage itself; also, more normalized organizations may have greater resources to spare in coverage of often unpopular public affairs news. Normalization occurs over time, and so older media platforms are generally more normalized than newer ones. The result of this is that platforms at different levels of normalization tend to have different 'prototypical message content' (Entman, 2005). That is, we can expect that a prototypical message from a more normalized platform (The Washington Post or newspapers, in general) is more likely to be relevant to public life than the prototypical message from a less normalized platform (Snapchat Discover or mobile apps, in general).

\section{Interactivity}

This refers to the extent to which the user's input is considered as part of the consumption experience (Eveland, 2003). This could include customization and personalization of news feeds in advance of consumption (whether via human input or algorithmically), story selection, and non-linear exploration (hyperlinks) during consumption, and expression and sharing after consumption. The full range of these capabilities is available only on digital news platforms, although the affordances of mobile phones and their integration with social networks and messaging give them an interactivity edge over computers. Television, on the other hand, is considered a much more passive experience (Rubin and Perse, 1987; Webster and Wakshlag, 1983). Interactivity is important to civic engagement because it influences elaboration, social capital, and network strength, all of which positively affect participation (Eveland, 2004; Gil de Zúñiga et al., 2012).

\section{Media repertoires and multiplatform news consumption}

When the Internet became popular, much research began comparing its users to those who used more traditional media. Now, however, the term 'internet user' holds little significance, especially in developed countries where internet penetration is around 90 percent (Internet Live Stats, 2016). It is not much different in the case of the smartphone, a device owned by more than 80 percent of US adults under age 50 (Anderson, 2015). Evidence suggests that smartphone use is increasing overall time spent with digital media, rather than simply displacing computers (ComScore, 2016). Now, news consumers may be 'omnivores', consuming media on all available platforms (Edgerly, 2015).

In an effort to account for the wide (and growing) range of technological platforms people use to consume media, scholars have suggested that people develop 'repertoires' of various media that suit their individual tastes, circumstances, and needs (Reagan, 1996; Yuan, 2011). The media repertoires approach is a significant advance in efforts to jointly analyze the effects of platform and content, but has been limited in its implementation.

A major challenge in this line of research is finding any commonality among the repertoires identified by the various studies. Without agreement on how to identify repertoires, the heuristic value of any individual repertoire is minimal. Media repertoires are highly idiosyncratic and diverse, making groupings around loosely assembled constellations of 
media-use patterns subject to inconsistency and misinterpretation. What is more, many of these media 'repertoires' identified using factor analysis end up centering on a single platform. Yuan (2011) and Taneja et al. (2012) both find a group centered on mobile phones and another around internet use to the exclusion of other platforms; Wolf and Schnauber (2015) find groupings centered on traditional media platforms; Edgerly (2015) identifies an 'online only' repertoire. Repertoire in these cases cannot refer to variety in platforms or the mix of platforms used but simply to platform preference. This does not reflect the multiplatform, 'convergence culture' (Jenkins, 2006) that defines the modern media age.

A second difficulty with this line of research is that identification and naming of media repertoires often conflate platform, content, and consumption patterns. Consider, for instance, the repertoires identified as 'computing for work' (Taneja et al., 2012), 'traditional seekers' (Lee and Yang, 2014), and 'TV-Oriented Entertainment' and 'News on Traditional Media' (Kim, 2016). Another study does not offer names but describes clusters of users like this to cite one example: 'mainly relies on the television set and their mobile device, complemented by an average use of the computer for information purposes' (Wolf and Schnauber, 2015). Elements of platform and content inform the identification of these groups, but lumping them together obscures details of the roles each plays in media consumption and civic life. These interrelated factors - platform and content - might each make a contribution to civic engagement, and so this study considers them separately before examining how they work together.

\section{Research questions}

Previous research has shown there to be differences in how news platforms and content contribute to civic engagement. It is possible that new platforms and the new differentiations in content they enable, as well as various combinations of platforms, are having profound effects on civic engagement. It is just as likely that, because of the range of social and personal influences that determine a person's propensity for civic engagement, the platform on which one gets their news has no measurable effect on engagement in civic life:

$R Q 1$. How do news platforms differ in their contributions to civic engagement?

It will also be important to determine how various forms of news content stack up to political news, long viewed as the primary contributor to civic engagement. This study focuses on news content, but even this has now expanded to include various topics and forms. While political news has consistently shown connections to civic engagement, studies of other forms of news content have been mixed:

$R Q 2$. How do types of news content differ in their contributions to civic engagement?

To further our understanding of these platforms and content, it is also important to build on the study of media repertoires to explore their combined influence. That is, does either platform or content make a more significant contribution than the other? Are their 
effects dependent on one another? Are there certain combinations of platform and content that are particularly beneficial or detrimental? And how can we understand news' contribution to civic engagement in a complicated, multiplatform media environment?

RQ3. How do platform and content work together to contribute to civic engagement?

\section{Methods}

Data for this study come from an online national survey of US adults. 1 Respondents for the survey were provided by Survey Sampling International (SSI) and were part of a managed panel that closely matches the demographics of all US adults. The panel was matched to data collected by the US Census Bureau on gender and race or ethnicity. Although this is a non-probability sample, when samples are matched on key demographics, the managed panel sample will converge with a true random sample under most circumstances as sample size increases (Rivers, 2005). Furthermore, this study seeks connections among theoretical constructs rather than true population estimates.

SSI gives all its panelists the opportunity to participate in surveys and does not send out unique invitations, making response rate calculations impossible. It was possible to record that 1706 respondents started the survey, 189 respondents dropped out at some point in the survey (for a refusal rate of $11 \%$ ), and 17 others were screened out because they did not meet the survey requirements (US resident age 18 or older). This left 1500 valid responses collected in April 2016. Respondents completed an online questionnaire asking about their news consumption habits, civic engagement, and demographic information.

\section{Demographics}

The sample was 61 percent White, 18 percent Hispanic or Latino, and 13 percent Black (nearly matching US Census results of $62 \%, 16 \%$, and $13 \%$, respectively). This variable was dichotomized as $0=$ minority and $1=$ White for the purposes of regression analysis. The sample was 51 percent female and 49 percent male. Respondent ages ranged from 18 to $87(\mathrm{M}=41$, standard deviation $(\mathrm{SD})=15.2)$. Just less than half of the respondents $(47 \%)$ had a college degree or better. About half of the respondents $(48 \%)$ reported making less than US\$50,000 a year. These demographic variables (age, race, gender, income, and education) are included as controls because of their effect on both news consumption and civic engagement.

\section{Control variables}

Paying for news. This variable is used as a control because of the likelihood that it represents a strong propensity for news consumption. This study is focused not on user interest or desire but on user choice of platforms. It also removes additional effects of socioeconomic status in addition to controlling for income directly. Respondents were asked which of the following subscriptions they pay for: music; video, including TV 
and movies; sports; and news. Only 20 percent of respondents said that they paid for a subscription to news.

Overall news consumption. This control variable accounts for the fact that some people simply get more news than others, a practice that should be related to civic engagement. This study is not concerned with the amount of news a person consumes but rather where they consume it and what types of news they consume. 2 Respondents were asked how many days in an average week they get news $(0-7, \mathrm{M}=5.5, \mathrm{SD}=2.1)$. All but 75 respondents said they get news at least 1 day per week, on average; the most common response was 7 days a week $(\mathrm{N}=821,55 \%)$.

\section{News consumption variables}

Platforms. Respondents were asked about how many days per week, on average, they get news on the following platforms: smartphone, printed newspaper, TV, laptop or desktop computer, radio, and tablet. These variables ranged from 0 (meaning they never get news on this platform) to 7 (every day of the week). Descriptive statistics are as follows: printed newspaper $(\mathrm{M}=2.25, \mathrm{SD}=2.48)$, radio $(\mathrm{M}=2.68, \mathrm{SD}=2.51), \mathrm{TV}(\mathrm{M}=4.38$, $\mathrm{SD}=2.47)$, computer $(\mathrm{M}=3.58, \mathrm{SD}=2.61)$, smartphone $(\mathrm{M}=4.01, \mathrm{SD}=2.72)$, and tablet $(\mathrm{M}=1.84, \mathrm{SD}=2.37)$. Respondents were also asked, 'When you do get news, from what platform do you usually access it?' The list of possible responses to this question included the six platforms already mentioned, plus print magazine, e-reader, and separate options for laptop and desktop computers.

Content. Respondents were asked how often they pay attention to a range of news categories on a scale of $1-4$, representing never, occasionally, sometimes, and often. These responses were subjected to a factor analysis in order to determine patterns of news interest because there is substantial overlap between categories. The results of this analysis are presented in Table 1. Three factors emerged,3 which are dubbed political news, topics news, and breaking news. The items in these factors were used to create three index variables (by summing responses and then dividing by the number of items in the index) that measure the attention a respondent pays to these kinds of news: political news attention $(\mathrm{M}=3.04, \mathrm{SD}=.78, \alpha=.84)$, topics news attention $(\mathrm{M}=2.60, \mathrm{SD}=.64, \alpha=.78)$, and breaking news attention $(\mathrm{M}=3.30, \mathrm{SD}=.68, \alpha=.80)$

\section{Civic engagement}

Political participation and civic participation have been studied as separate concepts (Gil de Zúñiga et al., 2010; Rojas and Puig-i-Abril, 2009; Zhong, 2014), but both make contributions to public life and so are included under civic engagement as a single concept. A growing number of behaviors may now be considered civic in nature, including boycotts, online expression, mobilization, and more (Dalton, 2008; Zukin et al., 2006). Thus, civic engagement was measured with eight items that cover a range of civic activities occurring online and offline. They include items usually designated as political participation (voting, contacting an elected official, and donating money to a campaign) and items 
Table I. Principal components factor analysis identifying patterns of news interest.

\begin{tabular}{|c|c|c|c|}
\hline \multirow{2}{*}{ Factor name } & \multicolumn{3}{|c|}{ Component } \\
\hline & I & 2 & 3 \\
\hline \multicolumn{4}{|l|}{ Political news } \\
\hline Political news & .779 & .311 & .157 \\
\hline National news & .731 & .082 & .375 \\
\hline International news & .719 & .156 & .221 \\
\hline 2016 Presidential election news & .717 & .239 & .285 \\
\hline \multicolumn{4}{|l|}{ Topics news } \\
\hline Arts and culture news & .195 & .760 & .010 \\
\hline Health news & .203 & .624 & .358 \\
\hline Celebrity and entertainment news & -.213 & .589 & .283 \\
\hline Business news & .523 & .588 & .020 \\
\hline Environment news & .232 & .579 & .381 \\
\hline Technology news & .336 & .574 & .219 \\
\hline Sports news & .208 & .419 & .043 \\
\hline \multicolumn{4}{|l|}{ Breaking news } \\
\hline Local news & .244 & .077 & .758 \\
\hline Breaking news & .333 & .178 & .732 \\
\hline Crime, accident, and disaster news & .112 & .311 & .731 \\
\hline Weather news & .173 & .120 & .687 \\
\hline
\end{tabular}

usually designated as civic participation (attending a community meeting, signing or sharing a petition, donating money or volunteering for charity, and boycotting a product). Respondents were asked whether they had done any of these activities in the past year, whether they voted in the 2012 presidential election, and whether they intend to vote in 2016. Responses were summed to create an index of civic engagement ranging from 0 to $8(\mathrm{M}=3.46, \mathrm{SD}=2.11, \alpha=.72)$.

\section{Results}

\section{Platforms}

The first research question asked how news platforms differ in their contributions to civic engagement? Respondents reported getting news from a wide range of platforms (see Table 2). Digital media, including smartphones and computers, and television top the list of the platforms most often used for news among these respondents.

To determine the unique contributions of individual platforms to civic engagement, the variables measuring use of the six platforms studied were entered into a regression model predicting civic engagement. The model included demographic variables (age, gender, race, income, and education) in the first block, control variables (paying for news and seeking news) in the second block, and the variables representing the use of each platform for news in the third block (see Table 3). Results show that use of all platforms 
Table 2. Platforms used for news consumption.

\begin{tabular}{|c|c|c|c|c|}
\hline \multirow[t]{2}{*}{ Platforms } & \multicolumn{2}{|c|}{$\begin{array}{l}\text { On which platform do you } \\
\text { 'usually' get news? }\end{array}$} & \multicolumn{2}{|c|}{$\begin{array}{l}\text { Get news on this platform at } \\
\text { least once a week }\end{array}$} \\
\hline & $\mathrm{N}$ & $\%$ & $\mathrm{~N}$ & $\%$ \\
\hline Smartphone & 583 & 38.9 & 1177 & 80.0 \\
\hline TV & 431 & 28.7 & 1299 & 88.5 \\
\hline Laptop & 167 & II.I & $*$ & $*$ \\
\hline Desktop & 121 & 8.1 & 1177 & 80.0 \\
\hline Tablet computer & 78 & 5.2 & 716 & 47.7 \\
\hline Printed newspaper & 55 & 3.7 & 889 & 60.8 \\
\hline Radio & 30 & 2.0 & 968 & 65.7 \\
\hline I don't usually get news & 24 & 1.6 & & \\
\hline Print magazine & 5 & .3 & & \\
\hline E-reader & 4 & .3 & & \\
\hline Other & 2 & .1 & & \\
\hline Total & 1500 & 100 & 1500 & N/A \\
\hline
\end{tabular}

*In the questions asking how many days per week respondents get news on each of six platforms, laptop and desktop computers were combined as 'on a computer'. The other items were not listed.

significantly predicted civic engagement. The strongest of these was print $(\beta=.115$, $\mathrm{p}<.001)$, followed closely by the smartphone $(\beta=.114, \mathrm{p}<.001)$ and computer $(\beta=.109$, $\mathrm{p}<.001)$. Television news use was also significantly related to civic engagement, but the coefficient was negative $(\beta=-.085, \mathrm{p}<.01)$. Together these variables representing news consumption on six platforms accounted for 5.9 percent of variance in civic engagement (Total $\mathrm{R}^{2}=26.9 \%$ ).

To further examine what might be happening with television, the variable indicating the platform from which a respondent usually gets news was used to create dummy variables, with television as the reference category. These were entered into a regression model with the same demographic and control variables as before. Thus, coefficients compare levels of civic engagement between those who prefer a given platform and those who prefer television. All platforms, except tablet $(\beta=.036, p=.164)$, had positive and significant coefficients, the highest of which was smartphone $(\beta=.131, p<.001)$. Respondents who prefer to get news from platforms other than television show higher levels of civic engagement than those who prefer to get news from television.

\section{Content}

The second research question asks how types of news content compare in their contributions to civic engagement. Again, this question focuses on the unique influence of each content type on civic engagement. To answer this research question, the indices measuring political news attention, topics news attention, and breaking news attention were entered into a regression model predicting civic engagement, after including the same demographic and control variables (see Table 3). Results show that political news 
Table 3. Regression models predicting the effects of news platforms and news content on civic engagement $(N=1248)$.

\begin{tabular}{|c|c|c|c|}
\hline & $\begin{array}{l}\text { Model I: platform } \\
\text { effects }\end{array}$ & $\begin{array}{l}\text { Model 2: content } \\
\text { effects }\end{array}$ & $\begin{array}{l}\text { Model 3: platforms } \\
\text { and content }\end{array}$ \\
\hline \multicolumn{4}{|l|}{ Demographics } \\
\hline Age & $.081 *$ & .013 & $.060^{*}$ \\
\hline Gender (male) & .028 & -.002 & -.010 \\
\hline Race (White) & .033 & .032 & .026 \\
\hline Education & $.112 * * *$ & $.112 * * *$ & $.103 * * *$ \\
\hline \multirow[t]{2}{*}{ Income } & $.081 * *$ & $.094 * *$ & $.06 I^{*}$ \\
\hline & $\Delta \mathrm{R}^{2}=10.8 \% * * *$ & $\Delta \mathrm{R}^{2}=1 \mathrm{I} .5^{* * *}$ & $\Delta \mathrm{R}^{2}=11.2^{* * *}$ \\
\hline \multicolumn{4}{|l|}{ Control variables } \\
\hline Paying for news & $.185^{* * *}$ & $.218 * * *$ & $.169 * * *$ \\
\hline \multirow[t]{2}{*}{ Seeking news } & $.090 * *$ & $.097 * *$ & .024 \\
\hline & $\Delta \mathrm{R}^{2}=10.2 \% * * *$ & $\Delta \mathrm{R}^{2}=11.5 \% * * *$ & $\Delta \mathrm{R}^{2}=10.0 * * *$ \\
\hline \multicolumn{4}{|l|}{ Platforms } \\
\hline Print & $.115^{* * *}$ & & $.105^{* * * *}$ \\
\hline Radio & $.089 * *$ & & $.080 * *$ \\
\hline Television & $-.085^{* *}$ & & $-.079 *$ \\
\hline Computer & $.109 * * *$ & & $.078 * *$ \\
\hline Smartphone & $.114 * *$ & & $.103^{* *}$ \\
\hline \multirow[t]{2}{*}{ Tablet } & $.060^{*}$ & & $.060 *$ \\
\hline & $\Delta \mathrm{R}^{2}=5.9 \% * * *$ & & $\Delta \mathrm{R}^{2}=5.8 \% * * *$ \\
\hline \multicolumn{4}{|l|}{ Content } \\
\hline Political news attention & & $.316 * * *$ & $.282 * * *$ \\
\hline Topics news attention & & $.067 *$ & -.018 \\
\hline \multirow[t]{2}{*}{ Breaking news attention } & & $-.114 * * *$ & $-.098 * *$ \\
\hline & & $\Delta \mathrm{R}^{2}=6.4 \% * * *$ & $\Delta \mathrm{R}^{2}=4.6 * * *$ \\
\hline Variance explained & Total $\mathrm{R}^{2}=26.9 \% * * *$ & Total $\mathrm{R}^{2}=29.4 \% * * *$ & Total $\mathrm{R}^{2}=31.6 \% * * *$ \\
\hline
\end{tabular}

OLS: ordinary least squares.

Cell entries are final entry OLS standardized coefficients $(\beta)$.

$*_{p}<.05, * * p<.01, * * * p<.001$.

attention is a strong positive predictor of civic engagement $(\beta=.316, p<.001)$. Attention to topics news, including technology, sports, the environment, business, and so on, is also weakly related to civic engagement $(\beta=.067, \mathrm{p}<.05)$. Attention to breaking news, including weather, crime, disasters, and local news, had a significant negative effect on civic engagement $(\beta=-.114, p<.001)$. Together, these three types of content explained 6.4 percent of variance in civic engagement (Total $\left.R^{2}=29.4 \%\right)$.

\section{Mixing platforms and content}

The final research question asks how various kinds of platform and content work together to contribute to civic engagement. There are 64 possible unique combinations 
Table 4. Respondents who use the most common combinations of platforms for news or news media repertoires.

\begin{tabular}{lcr}
\hline Media repertoire & N & $\%$ \\
\hline All six platforms & 423 & 28.7 \\
All but tablet & 110 & 7.5 \\
All but print & 79 & 5.4 \\
All but print and tablet & 73 & 4.9 \\
TV, computer, and smartphone & 72 & 4.9 \\
\hline
\end{tabular}

of the six platforms studied (including the possibility of using none of them), and 60 of those combinations were found among respondents. The distribution of these combinations follows a power law, with one very popular combination, a few others employed by moderate percentages, and the rest used by only small numbers of respondents (the last 32 combinations of platforms are used by fewer than 10 respondents each). The most common media repertoire, by far, was to use all six platforms for news at least 1 day a week ( $29 \%$ of respondents). The next four most popular repertoires (accounting for another $23 \%$ of respondents) all include TV, computer, and smartphone (see Table 4). An analysis of variance (ANOVA; see Table 5) controlling for the same demographic and intent variables as before showed that those who use all six platforms for news had significantly higher levels of civic engagement $(M=4.50, S D=2.22)$ than those who used any other combination of platforms $(\mathrm{M}=3.48, \mathrm{SD}=2.09 ; \mathrm{F}(1,1232)=42.392$, $\mathrm{p}<.001)$. To test this another way, the number of platforms a person uses to get news was entered into a regression model predicting civic engagement along with the same demographic and news intent variables as controls. Results show that the more platforms a person uses for news, the higher their levels of civic engagement $(\beta=.217$, $\left.\mathrm{p}<.001, \Delta \mathrm{R}^{2}=3.5 \% * * *\right)$.

The question of how platform and content work together is more difficult to answer. Interaction terms for several combinations of platform and content (including print $\times$ political news, TV $\times$ political news, $\mathrm{TV} \times$ breaking news, smartphone $\times$ political news, smartphone $\times$ breaking news, radio $\times$ breaking news, among others) were computed and tested, but none were found to be significant. Partial correlations between platforms and content present a mixed picture (see Table 6). The strongest correlation in the table is between television and breaking news $(\mathrm{r}=.265, \mathrm{p}<.001)$, the two factors that had negative effects on civic engagement. Other platforms are also correlated with breaking news but much less strongly (all less than .083 for radio). But television is also correlated with the other two types of news attention. Topics news attention correlated with use of all platforms, and political news attention correlated most strongly with computer $(\mathrm{r}=.220, \mathrm{p}<.001)$, television $(\mathrm{r}=.168, \mathrm{p}<.001)$, and smartphone $(\mathrm{r}=.097, \mathrm{p}<.05)$.

Finally, additional regression analyses reveal that some of the same people are watching TV and paying attention to breaking news - the older and less educated. Age $(\beta=.226$, $\mathrm{p}<.001)$ and education $(\beta=-.081, \mathrm{p}<.01)$ significantly predicted the use of television for news; age $(\beta=.125, \mathrm{p}<.001)$ and education $(\beta=-.123, \mathrm{p}<.001)$ also significantly predicted attention to breaking news. 
Table 5. Levels of civic engagement among users of multiple platforms for news.

\begin{tabular}{lllr}
\hline Platforms used & \multicolumn{2}{c}{ Civic engagement score } & $\mathrm{N}$ \\
\cline { 2 - 4 } & Mean & SD & \\
\hline 0 & 1.18 & 1.17 & 11 \\
1 & 1.60 & 1.23 & 42 \\
2 & 2.71 & 1.87 & 124 \\
3 & 2.85 & 1.79 & 254 \\
4 & 3.33 & 1.91 & $26 \mathrm{I}$ \\
5 & 3.66 & 1.84 & 214 \\
6 & 4.50 & 2.22 & 356 \\
Total & 3.48 & 2.09 & 1262 \\
\hline
\end{tabular}

SD: standard deviation.

Table 6. Partial correlations between news platforms and news content types after controlling for demographics and intentional news consumption $(N=1300)$.

\begin{tabular}{lllllll}
\hline & Print & Radio & TV & Computer & Smartphone & Tablet \\
\hline Political news attention & $.070^{*}$ & $.069^{*}$ & $.168^{* * *}$ & $.220^{* * *}$ & $.097^{* * *}$ & $.065^{*}$ \\
Topics news attention & $.250^{* * *}$ & $.168^{* * *}$ & $.174^{* * *}$ & $.218^{* * *}$ & $.164^{* * *}$ & $.184^{* * *}$ \\
Breaking news attention & $.059^{*}$ & $.083^{* *}$ & $.265^{* * *}$ & $.081^{* *}$ & $.066^{*}$ & $.063^{*}$ \\
\hline
\end{tabular}

Cell entries are partial correlation ( $r$ ) coefficients, controlling for age, gender, race, income, education, paying for news, and overall news consumption.

$*_{\mathrm{p}}<.05, * * \mathrm{p}<.01, * * * \mathrm{p}<.001$.

\section{Discussion}

This study sought to move beyond dichotomous treatments of media consumption patterns (digital vs legacy, hard vs soft) and test the unique contributions of news media platforms to civic engagement in a multimedia, multiplatform environment. Indeed, respondents in this study get news on multiple platforms in the course of a week, with more than a quarter of them using all six platforms studied. Respondents combined these platforms into 60 different media repertoires, but, overall, frequently relied on digital media, including smartphones and computers. This confirms that the news media landscape is more varied than ever. It no longer makes sense to focus on individual platforms in studies of news consumption, and it may not make sense to focus on a user's preferred news platform. Even if many people list smartphone as their preferred news platform, they are clearly getting substantial amounts of news from other platforms as well.

The good news is that more is better in the case of civic engagement. The more platforms a person used to get news, the higher their levels of civic engagement. Many newsmakers have worried that audience attention is now spread too thin as people jump from platform to platform, story to story, and some research supports this worry (Dunaway et al., 2016; Molyneux, 2018). The suggestion is that this helter-skelter 
consumption pattern is one of distractions rather than attentiveness. But the evidence here suggests that the most varied condition (getting news on all six platforms studied) is the most beneficial for civic engagement. This may be because platforms have complementary strengths and weaknesses - a lack of interactivity on television supplemented by smartphone use, a lack of information density on the smartphone supplemented by computer or newspaper use, and so on. These data cannot confirm directionality, so it may also be that the most engaged people seek out news on multiple platforms, while those who are less engaged avoid news on most platforms. Still, it appears that practitioners may benefit from encouraging audiences to consume news across many platforms rather than worrying that one platform will cannibalize another's audience. Educators and others interested in engaging the public would be wise to approach them in multiple media and through varying types of content, enabling not only a wider reach but also message repetition as consumers encounter their content on multiple platforms.

The upshot in terms of civic engagement is that not all of these platforms are equally helpful. The case of television is particularly troubling. It is not merely that getting news on TV makes no contribution to civic engagement - getting news on TV is actually associated with lower levels of civic engagement. This is true even when accounting for demographic variables, the overall amount of news a person gets, and the types of content a person consumes. A number of factors may be contributing to this. First, television is generally considered a passive medium with the lowest level of interactivity among the platforms studied. This is closely related to a second point, which is that television users are likely to be distracted - second screening, perhaps (Gil de Zúñiga et al., 2015), or doing household chores while the TV is on. Third, the television has low information density compared to other formats, and the user has no control over which news stories to consume during an evening newscast (other than changing the channel). Finally, while television news had a relatively high level of immediacy, it is possible that it has normalized with a preference for certain types of content - the breaking news that also showed a negative association with engagement.

In this case, platform and content overlap in a way that offers the worst of both worlds. Local news, crime, breaking news, and weather is a near-perfect description the evening local newscast, a mixture of platform and content that is still the single most-used source of news among the American public (Mitchell et al., 2016). Many have decried local news' focus on crime, disasters, and weather and lack of substantial reporting resources (for several examples, see McChesney and Pickard, 2011). The arguments are that little of the content in local newscasts focuses on matters of civic import, and stations are not in much of a position to fix it, given how newsrooms are shrinking. Television's strength has often been seen as immediacy, but this breaking news also loaded in the same factor as crime and weather and had negative effects on civic engagement. A possible explanation is that the rush to be first (in any medium) can have detrimental effects on journalism quality (Lewis and Cushion, 2009).

This study did not distinguish between the various sources available on each platform. Clearly, not all information sources available via computer are equally helpful; measures of content type account for some but not all of this variance. The purpose of this study was to focus on the unique contributions of platform and content, but future studies may further subdivide, for instance, separating cable and broadcast news. That distinction 
may be key if highly partisan programming (like the sort found on the two most popular cable news channels) has different effects from more normalized reporting (like broadcast channels still offer).

This study suggests that journalism practitioners, especially those working in local television news, should not assume that their content is democratically valuable. While the platform itself may have weaknesses in terms of interactivity and information density, perhaps, these may be overcome through a focus on types of content that contribute more to public life. Perhaps, local television news was never meant to be a civic information resource, and instead, serves some other informational purpose. It is also possible that television attracts those who are already disengaged from public life. If that is the case, it may be that vicious and virtuous engagement cycles are at work, with the least engaged of us also least likely to encounter information about public affairs. It may not be entirely within the power of broadcasters to break this cycle, but they can at least evaluate whether the content they produce meets their democratic and economic goals.

The results presented here come from a cross-sectional survey of US adults. As such, causality cannot be inferred, and the results may not be applicable globally. The US media and political situation are unique, and these findings may not be indicative of other media systems. These data provide a portrait of associations in media consumption and civic engagement at a time when media offerings are increasingly diverse and during an election year when civic and political activity is typically heightened. This study is also limited by its focus on platforms and news content, largely ignoring larger, more complicated pathways to civic engagement. Efforts were made to control for other key variables that affect media consumption and civic engagement, but this study does not account for all possible influences. Still, the findings suggest that there are differences in how each platform and content type contribute to civic engagement, which was the purpose of this study.

Those seeking to encourage civic engagement among news consumers should consider the multiplatform nature of news consumption and seek to meet news audiences across all distribution formats. Advertisers and others have already picked up on these patterns of consumption and are re-targeting content to consumers across devices (Lambrecht and Tucker, 2013; Pariser, 2011). Thinking of audiences in silos based on the platform (such as the mobile audience) is a short-sighted approach to engaging them. Many consumers are developing habits that lead them to consume news on multiple platforms, and in the case of civic engagement, the most varied condition is the best one.

\section{Funding}

The author(s) disclosed receipt of the following financial support for the research, authorship, and/ or publication of this article: This research was supported by a faculty research grant from Temple University.

\section{Notes}

1. The survey was developed and fielded as part of a research partnership between the author and Dr. Paula Poindexter of the University of Texas at Austin, who purchased the respondent pool from Survey Sampling International.

2. This variable did not display problematic collinearity with the platform-specific news consumption variables. All variance inflation factors (VIF) were less than 1.7. 
3. It should be noted that business news loaded strongly on both the political news and topics news factors, but had a higher coefficient with topics news and fit that category conceptually.

\section{References}

Althaus SL and Tewksbury D (2002) Agenda setting and the 'new' news: Patterns of issue importance among readers of the paper and online versions of The New York Times. Communication Research 29(2): 180-207. Available at: https://doi.org/10.1177/0093650202029002004

Anderson M (2015) Technology device ownership. Available at: http://www.pewinternet. org/2015/10/29/technology-device-ownership-2015/ (accessed 4 November 2015).

Beaudoin CE (2009) Exploring the association between news use and social capital: Evidence of variance by ethnicity and medium. Communication Research 36(5): 611-636. Available at: https://doi.org/10.1177/0093650209338905

Campbell SW and Kwak N (2010) Mobile communication and civic life: Linking patterns of use to civic and political engagement. Journal of Communication 60(3): 536-555. Available at: https://doi.org/10.1111/j.1460-2466.2010.01496.x

Campbell SW and Kwak N (2011) Mobile communication and civil society: Linking patterns and places of use to engagement with others in public. Human Communication Research 37(2): 207. Available at: https://doi.org/10.1111/j.1468-2958.2010.01399.x

ComScore (2016) The 2016 U.S. Mobile App Report. Available at: https://www.comscore.com/ Insights/Presentations-and-Whitepapers/2016/The-2016-US-Mobile-App-Report

Dalton RJ (2008) The Good Citizen: How a Younger Generation Is Reshaping American Politics. London: SAGE.

Delli Carpini MX (n.d.) Civic engagement. American Psychological Association. Available at: http://www.apa.org/education/undergrad/civic-engagement.aspx

Dholakia N, Reyes I and Bonoff J (2015) Mobile media: From legato to staccato, isochronal consumptionscapes. Consumption Markets \& Culture 18: 10-24. Available at: https://doi.org/10 $.1080 / 10253866.2014 .899216$

Dimmick J, Feaster JC and Hoplamazian GJ (2010) News in the interstices: The niches of mobile media in space and time. New Media \& Society 13(1): 23-39. Available at: https://doi. org/10.1177/1461444810363452

Dunaway J, Paul N, Searles K, et al. (2016) Does (Screen) size matter? News engagement on computers, tablets and smartphones. In: Annual Meeting of the Midwest Political Science Association. Chicago, IL, 8 April 2016.

Edgerly S (2015) Red media, blue media, and purple media: News repertoires in the colorful media landscape. Journal of Broadcasting \& Electronic Media 59(1): 1-21. Available at: https:// doi.org/10.1080/08838151.2014.998220

Entman RM (2005) The nature and sources of news. In: Geneva Overholser and Kathleen Hall Jamieson (eds) Institutions of American Democracy: The Press. New York: Oxford University Press, pp. 48-65.

Eveland WP Jr (2003) A 'mix of attributes' Approach to the study of media effects and new communication technologies. Journal of Communication 53(3): 395-410. DOI: 10.1111/j.14602466.2003.tb02598.x.

Eveland WP Jr (2004) The effect of political discussion in producing informed citizens: The roles of information, motivation, and elaboration. Political Communication. 21: 177-193.

Eveland WP Jr and Dunwoody S (2002) An investigation of elaboration and selective scanning as mediators of learning from the web versus print. Journal of Broadcasting \& Electronic Media 46(1): 34-53. Available at: https://doi.org/10.1207/s15506878jobem4601_3 
Fleming K and Thorson E (2008) Assessing the role of information-processing strategies in learning from local news media about sources of social capital. Mass Communication and Society 11(4): 398-419. Available at: https://doi.org/10.1080/15205430801950643

Gil de Zúñiga H, Garcia-Perdomo V and McGregor SC (2015) What is second screening? Exploring motivations of second screen use and its effect on online political participation. Journal of Communication 65(5): 793-815. Available at: https://doi.org/10.1111/ jcom. 12174

Gil de Zúñiga H, Jung $\mathrm{N}$ and Valenzuela S (2012) Social media use for news and individuals' social capital, civic engagement and political participation. Journal of Computer-mediated Communication 17(3): 319-336. Available at: https://doi.org/10.1111/ j.1083-6101.2012.01574.x

Gil de Zúñiga H, Molyneux L and Zheng P (2014) Social media, political expression, and political participation: Panel analysis of lagged and concurrent relationships. Journal of Communication 64(4): 612-634. Available at: https://doi.org/10.1111/jcom.12103

Gil de Zúñiga H, Veenstra A, Vraga E, et al. (2010) Digital democracy: Reimagining pathways to political participation. Journal of Information Technology \& Politics 7(1): 36-51. Available at: https://doi.org/10.1080/19331680903316742

Hardy BW and Jamieson KH (2011) Clicking to learn during the 2008 presidential election: Why capturing channel switching matters. Journal of Broadcasting \& Electronic Media 55(4): 470-489. Available at: https://doi.org/10.1080/08838151.2011.620669

Internet Live Stats (2016) Internet users by country (2016). Available at: http://www.internetlivestats.com/internet-users-by-country/ (accessed 27 September 2016).

Jenkins H (2006) Convergence Culture: Where Old and New Media Collide. New York: New York University Press.

Kim SJ (2016) A repertoire approach to cross-platform media use behavior. New Media \& Society 18(3): 353-372. Available at: https://doi.org/10.1177/1461444814543162

Kwak N, Campbell SW, Choi J, et al. (2011) Mobile communication and public affairs engagement in Korea: An examination of non-linear relationships between mobile phone use and engagement across age groups. Asian Journal of Communication. Available at: https://doi. org/10.1080/01292986.2011.587016

Lambrecht A and Tucker C (2013) When does retargeting work? Information specificity in online advertising. Journal of Marketing Research 50(5): 561-576. Available at: https://doi. org/10.1509/jmr.11.0503

Lane RE (1959) Political Life: Why and How People Get Involved in Politics. Glencoe; Wilmington, IL: The Free Press.

Lee $\mathrm{H}$ and Yang J (2014) Political knowledge gaps among news consumers with different news media repertoires across multiple platforms. International Journal of Communication 8. Available at: http://ijoc.org/index.php/ijoc/article/view/2455/1087

Lewis J and Cushion S (2009) The thirst to be first: An analysis of breaking news stories and their impact on the quality of 24 hour news coverage in the UK. Journalism Practice 3(3): 304-318. Available at: https://doi.org/10.1080/17512780902798737

McChesney RW and Pickard V (2011) Will the Last Reporter Please Turn Out the Lights: The Collapse of Journalism and What Can Be Done to Fix It. London: The New Press.

McCombs M (2004) Setting the Agenda: The Mass Media and Public Opinion. Cambridge; Malden, MA: Polity Press and Blackwell. Available at: http://www.amazon.com/dp/0745623131

Mitchell A, Gottfried J, Barthel M, et al. (2016) The modern news consumer: News attitudes and practices in the digital era. Available at: http://www.journalism.org/2016/07/07/the-modernnews-consumer/ 
Molyneux, Logan (2018) Mobile news consumption: A habit of snacking. Digital Journalism 6(5): 634-650.

Morris JS and Forgette R (2007) News grazers, television news, political knowledge, and engagement. The International Journal of Press/politics 12(1): 91-107. Available at: https://doi. org/10.1177/1081180X06297122

Neuman WR, Bimber B and Hindman M (2011) The Internet and four dimensions of citizenship. The Oxford Handbook of American Public Opinion and the Media. Epub ahead of print May. DOI: 10.1093/oxfordhb/9780199545636.003.0002.

Neuman WR, Just MR and Crigler AN (1992) Common Knowledge: News and the Construction of Political Meaning (American Politics and Political Economy Series). Chicago, IL: University of Chicago Press.

Norris P (1996) Does television erode social capital? A reply to Putnam. PS: Political Science \& Politics 29: 474-480.

Pariser E (2011) The Filter Bubble: What the Internet Is Hiding from You. London: Penguin Books. Patterson T E (2013) Informing the News. New York: Vintage.

Price V, Nir L and Cappella JN (2006) Normative and informational influences in online political discussions. Communication Theory 16(1): 47-74. Available at: https://doi.org/10.1111/ j.1468-2885.2006.00005.x

Prior M (2003) Any good news in soft news? The impact of soft news preference on political knowledge. Political Communication 20(2): 149-171. Available at: https://doi. org/10.1080/10584600390211172

Prior M (2005) News vs. entertainment: How increasing media choice widens gaps in political knowledge and turnout. American Journal of Political Science 49(3): 577-592.

Putnam R (2000) Bowling Alone: The Collapse and Revival of American Community. New York: Simon \& Schuster.

Reagan J (1996) The 'repertoire'; of information sources. Journal of Broadcasting \& Electronic Media 40(1): 112-121. Available at: https://doi.org/10.1080/08838159609364336

Reinemann C, Stanyer J, Scherr S, et al. (2011) Hard and soft news: A review of concepts, operationalizations and key findings. Journalism 13(2): 221-239. Available at: https://doi. org/10.1177/1464884911427803

Rivers D (2007) “Sampling for Web Surveys.” In Joint Statistical Meetings. Available at: http:// www.laits.utexas.edu/txp_media/html/poll/files/Rivers_matching.pdf.

Rojas H and Puig-i-Abril E (2009) Mobilizers mobilized: Information, expression, mobilization and participation in the digital age. Journal of Computer-mediated Communication 14(4): 902-927. Available at: https://doi.org/10.1111/j.1083-6101.2009.01475.x

Rubin AM andPerseEM(1987) Audience activity and televisionnews gratifications. Communication Research 14(1): 58-84. Available at: https://doi.org/10.1177/009365087014001004

Ruston Scott W (2012) Calling ahead: Cinematic imaginations of mobile media's critical affordances. In: Noah Arceneaux and Anandam Kavoor (eds) The Mobile Media Reader. New York: Peter Lang, pp. 23-39.

Santana A, Livingstone RM and Cho YY (2013) Print readers recall more than do online readers. Newspaper Research Journal 34(2): 78-92.

Sayre B, Bode L, Shah DV, et al. (2010) Agenda setting in a digital age: Tracking attention to California proposition 8 in social media, online news and conventional news. Policy \& Internet 2(2): 7. Available at: https://doi.org/10.2202/1944-2866.1040

Scheufele DA and Shah DV (2000) Personality strength and social capital: The role of dispositional and informational variables in the production of civic participation. Communication Research 27(2): 107-131. Available at: https://doi.org/10.1177/009365000027002001 
Shah DV (1998) Civic engagement, interpersonal trust, and television use: An individual-level assessment of social capital. Political Psychology 19(3): 469-496. Available at: https://doi. org $/ 10.1177 / 009365000027002001$

Singer Jane B (2005) The political J-blogger: 'Normalizing' a new media form to fit old norms and practices. Journalism 6(2): 173-198.

Taneja H, Webster JG, Malthouse EC, et al. (2012) Media consumption across platforms: Identifying user-defined repertoires. New Media \& Society 14(6): 951-968. Available at: https://doi.org/10.1177/1461444811436146

Tewksbury D and Althaus SL (2000) Differences in knowledge acquisition among readers of the paper and online versions of a national newspaper. Journalism \& Mass Communication Quarterly 77(3): 457-479. Available at: https://doi.org/10.1177/107769900007700301

Tewksbury DAJ, Weaver BD and Maddex (2001) Accidentally informed: Incidental news exposure on the world wide web. Journalism \& Mass Communication Quarterly 78: 533-554.

Tien-Tsung L, Lu W, Lee T, et al. (2008) How newspaper readership affects political participation. Newspaper Research Journal 29(3): 8-23.

Uslaner EM (1998) Social capital, television, and the 'mean world': Trust, optimism, and civic participation. Political Psychology 19(3): 441-467. Available at: https://doi.org/10.1111/0162895X.00113

Verba S and Nie NH (1972) Participation in America: Political Democracy and Social Equality. Evanston, IL: Harper \& Row.

Verba S, Schlozman KL and Brady HE (1995) Voice and Equality: Civic Voluntarism in American Politics vol. 4. Cambridge: Cambridge University Press.

Webster JG and Wakshlag JJ (1983) A theory of television program choice. Communication Research 10(4): 430-446. Available at: https://doi.org/10.1177/009365083010004002

Wolf C and Schnauber A (2015) News consumption in the mobile era. Digital Journalism 3(5): 759-776. Available at: https://doi.org/10.1080/21670811.2014.942497

Yang J and Grabe ME (2011) Knowledge acquisition gaps: A comparison of print versus online news sources. New Media \& Society 13(8): 1211-1227. Available at: https://doi. org/10.1177/1461444811401708

Yuan E (2011) News consumption across multiple media platforms. Information, Communication \& Society 14(7): 998-1016. Available at: https://doi.org/10.1080/1369118X.2010.549235

Zhong Z-J (2014) Civic engagement among educated Chinese youth: The role of SNS (Social Networking Services), bonding and bridging social capital. Computers \& Education 75: 263 273. Available at: https://doi.org/10.1016/j.compedu.2014.03.005

Zukin C, Keeter S, Andolina M, et al. (2006) A New Engagement? Political Participation, Civic Life, and the Changing American Citizen. Oxford: Oxford University Press.

\section{Author biography}

Logan Molyneux is Assistant Professor in Temple University's Klein College of Media and Communication. His research focuses on journalism and technology. 